\title{
Fluctuating Environment Can Negate Cheater Success Due to Speed-Agility Trade-Off
}

\author{
Naomi Iris van den Berg ${ }^{1}$, Lajos Kalmar ${ }^{1}$, Kiran R. Patil ${ }^{1 *}$ \\ ${ }^{1}$ Medical Research Council Toxicology Unit, University of Cambridge \\ *Correspondence to: kp533@cam.ac.uk
}

Keywords: microbial evolution, diauxic shift, public goods, nutrient periodicity

10 Abstract

Stability of microbial cooperation through common goods is susceptible to cheating. Evidence suggests that cheating plays a less prominent role in many natural systems than hitherto predicted by models of eco-evolutionary dynamics and evolutionary game theory. While several cheater negating factors such as spatial segregation have been identified, most consider single-nutrient regimes. Here we propose a cheater-suppressing mechanism based on previous experimental observations regarding the biochemical trade-off between growth speed and delay in switching to alternative nutrients. As changing the nutrient source requires redistribution of enzymatic resources to different metabolic pathways, the advantage in speed is offset by lower agility due to longer time required for resource re-allocation. Using an in silico model system of sucrose utilisation by Saccharomyces cerevisiae, we find that a tradeoff between growth rate and diauxic lag duration can supress cheaters under fluctuating nutrient availability and thereby stabilise cooperation. The resulting temporal dynamics constrain cheaters despite their competitive benefit for the growth on the primary nutrient via avoided public goods synthesis costs. We further show that this speed-agility trade-off can function in synergy with spatial segregation to avoid the collapse of the community due to the cheaters. Taken together, the growth-agility trade-off may contribute to cheater suppression in microbial ecosystems experiencing fluctuating environments, such as plant root microbiota and gut microbiota. 


\section{Introduction}

Costs to cooperation provide a selective incentive to defect or cheat (Dumas \& Kummerli,

2012). Cheating describes an indirect harm done to non-cheating individuals in a (social) consortium. In contrast to parasites, which incite a direct harm, cheaters act via the intermediary of exploitable social behaviours, the public goods (Ghoul et al., 2014). Cheating cells avoid costs associated with contribution to, but benefit from, the public goods, and hence enjoy a competitive advantage over the cooperative cells. Despite this apparent advantage to the cheaters, cooperation is prevalent in nature, suggesting existence of cheater suppressing mechanisms. Cooperation has been shown to contribute to species and functional diversity; for example, a multi-species community can thrive even on a single carbon source, countering competition in driving ecological dynamics (Blasche et al., 2021; Estrela et al., 2021; Estrela et al., 2020; Goldford et al., 2018). Thus, understanding the mechanisms by which cheating is suppressed and stable cooperation is maintained is of importance in deciphering community structure, dynamics and function.

When unchecked, cheaters in a community can proliferate and disrupt the system's stability, leading to collapse (Fiegna \& Velicer, 2003; Kümmerli et al., 2015; Rainey \& Rainey, 2003; Rankin et al., 2007; Ross-Gillespie et al., 2007; Schuster et al., 2017). This extreme outcome would not only require cheater emergence (constrained mostly by stochastic mechanisms), but also cheater proliferation (constrained mostly by non-random, selective mechanisms) (Fiegna \& Velicer, 2003). There are three main families of identified mechanisms limiting cheater success. First, inter-group competition, also described as the Simpson's Paradox, limits the cheater's relative fitness when assessed from a group selection perspective: within any one group, cheaters outcompete non-cheaters, but groups with more cheaters are outcompeted by groups with relatively fewer cheaters (Chuang et al., 2009; $\underline{\text { Cremer et al., }}$ 2012; van Tatenhove-Pel et al., 2021). Second, cheaters are constrained by relatedness within the community, in accordance with kin(d)-selection theory (Bastiaans et al., 2016; Dennehy \&

Turner, 2004; Gilbert et al., 2007; Kuzdzal-Fick et al., 2011; Madgwick et al., 2018; $\underline{\text { Oliveira et }}$ al., 2014; Strassmann \& Queller, 2011). Third, cheaters can be constrained by mechanisms reducing their access to public goods. Proliferation of cheating mutants may be limited by pleiotropy (Foster et al., 2004), where lower expression of a cooperative trait is itself linked to lower access to a public good. Additionally, grouping together of cooperative cells, facilitated by spatial structuring, can induce a positive, density-dependent, local effect, with cooperative cells passively forming 'exclusivity zones' that halt further proliferation of cheating phenotypes (Bachmann et al., 2013; Cavaliere et al., 2017; Folse III \& Allison, 2012; Momeni et al., 2013; Nadell et al., 2009; Stump et al., 2018; Van Dyken et al., 2013). This spatial effect can also be made apparent through non-spatially explicit factors such as viscosity of growth media, with 
75 higher viscosity favouring cooperative phenotypes by lowering cell dispersal and public goods diffusion (Figueiredo et al., 2021; Kümmerli et al., 2009). Cheater access to public goods can also be actively undermined via enforcement. Enforcement mechanisms reward fellow cooperators and/or punish cheaters (Figueiredo et al., 2021; Ho et al., 2013; Schluter et al., 2015; Smukalla et al., 2008; Travisano \& Velicer, 2004). An example of enforcement is that of the rhizobia system in root nodules. If the rhizobia no longer supply fixed nitrogen to their host, the host responds by cutting off supply of carbon exudates to that specific root nodule (Westhoek et al., 2017).

However, these described mechanisms do not always succeed in explaining observed suppressed cheater success. As shown by MacLean and Gudelj (2006), cooperation can persist in homogenous populations, even in the absence of kin(d)-recognition or policing, indicating that other mechanisms are constraining proliferation of cheater cells. Similarly, Dobay et al. (2014) emphasised that interactions between key parameters of public goods cooperation give rise to more complex fitness landscapes, and thus that a further understanding of cooperation in the face of cheating requires multifactorial approaches. Undescribed interactions between multiple cheater-limiting mechanisms (and other (a)biotic processes) may weigh into the many cost-benefit trade-offs involved in microbial community interaction dynamics, and hence alter a cheater's selective landscape, keeping the role of cheating in natural microbial systems smaller than previously expected (Figueiredo et al., 2021; Waite \& Shou, 2012). These additional undescribed and often context-dependent costs thus subject the selective landscape of the cheater strategy to the Cheater's Dilemma: a set of trade-offs that mitigate the selective benefit imparted by reduced investments in public goods.

100 In this study, we explore the Cheater's Dilemma in the context of diauxic shifts. Diauxic shifts are common in microbial ecosystems, yet are underrepresented in microbial community modelling (Pacciani-Mori et al., 2020). Furthermore, in many natural systems, the primary substrate goes through cycles of supply and depletion, such as pulsed carbon additions to plant root microbiota (Berthrong et al., 2013) or pulsed substrate additions (reflecting daily eating patterns) to the gut microbiota (Koch, 1971; Pudlo et al., 2015). Pulsed availability of the primary substrate has been shown to influence community composition and dynamics (Carrero-Colón et al., 2006; Konopka et al., 2007), and may lead to sequential diauxic shifts. These diauxic shifts are characterised by a lag time, primarily due to catabolite repression and transcriptional reprogramming required for re-allocating enzymatic resources between the diauxic shift lag time have been identified (Chu \& Barnes, 2016; Salvy \& Hatzimanikatis, 
2021; Solopova et al., 2014), where Basan et al. (2020), New et al. (2014) and Fuentes et al. (2021) have showed that faster growing cells experience a longer lag time in shifting to the secondary substrate, whereas slower growing cells resume growth much more quickly. This

115 trade-off falls within an overarching, universal family of trade-offs, based on resource allocation constraints, between (microbial) growth rate and adaptation rate (Kim et al., 2020; Yi \& Dean, 2016). Since cheating on public goods production implies faster growth relative to non-cheaters (Ramin \& Allison, 2019; Raymond et al., 2012), we here hypothesise that diauxic shifts in a fluctuating environment impose a cost on cheaters. Using a coupled ODE model,

120 we show that the benefit of the cheater strategy depends not only on the relative cost of public good synthesis, but also on the fluctuation regime of the primary substrate and the delay in switching to the secondary substrate. The results bring forward the temporal cost of metabolic switching as an additional mechanism contributing to the Cheater's Dilemma.

\section{Model description}

To capture the cost to cheating in the context of diauxic shifts, we developed an ordinary differential equations (ODEs) model. We aimed to capture the dynamics of a cooperative microbial species in competition with a subgroup of isogenic cheater mutants. The primary resource in this system is the substrate $S$. We simulate a fluctuating environment with periodic

130 addition of the substrate to a set concentration, $S_{\max }$. This substrate needs to be hydrolysed into monomers $(M)$ in order to become accessible as a carbon/energy source. This is done via extracellular enzymes $(E)$ produced by the cooperative 'producer' cells $(P)$. The monomers form the common goods that the cheaters $(C)$ exploit. Both cell types produce a by-product, $B$, during their growth on $M$. When the substrate $S$ (and hence $M$ ) becomes unavailable, both

135 cell-types need to shift to the secondary resource $B$. However, cheaters experience a longer lag time for this shift than the producers, dictated by a constant, $\theta$, to account for the speedagility trade-off (see figure $1 \& 2$ ).

A concrete example of a microbial system resembling the model explored here is sucrose 140 utilisation by the yeast Saccharomyces cerevisiae. This model microbe has a long history of use in food and drink fermentations, and is also widely used in biotechnological applications such as production of biofuels and pharmaceuticals (Marques et al., 2016). Saccharomyces cerevisiae secretes invertase enzyme ( $\beta$-D-fructofuranosidase, E.C. 3.2.1.26) to hydrolyse sucrose. Ethanol is excreted as a by-product during growth, which can later be consumed 145 when the hydrolysed monosaccharides (i.e. glucose and/or fructose) are exhausted (Atiyeh \& Duvnjak, 2002; Gibb, 2018). The change from growth on sugars to growth on ethanol constitutes the diauxic shift. 
While the hydrolysis reaction via invertase is performed in the periplasmic space, it has been demonstrated that most ( $99 \%)$ of the monosaccharides released are extracellular and need

150 to be imported (Basso et al., 2011; Gore et al., 2009). Hence, invertase can, for the purpose of this study, be considered functionally equivalent to purely extracellular enzymes, as done by the previous studies looking into cheater dynamics in S. cerevisiae (Cavaliere et al., 2017; Chen et al., 2014; Gore et al., 2009; Greig \& Travisano, 2004; Koschwanez et al., 2011; Travisano \& Velicer, 2004; Van Dyken et al., 2013). The impact of pulsed carbon additions on

155 S. cerevisiae diauxic shift and growth has been studied extensively (Espinosa Vidal et al., 2015; Ronen \& Botstein, 2006; van den Brink et al., 2008), however, not in the context of cheater dynamics and the speed-agility trade-off.

In our model, we assume that the upper limit of glucose concentration leading to repression of invertase synthesis (as identified by Dueñas-Sánchez et al. (2012)) will not be reached due to the slow release and immediate uptake of glucose in our system. With ethanol as our byproduct, and periodic minimal additions of primary substrate, we assume its concentrations do not reach toxicity levels of $>10 \%$. Local structure allows the grouping together of cells, which decreases the likelihood of monomers diffusing too far away for consumption by producers, benefitting producer growth. This locality benefit does not apply for by-product uptake, since the by-products may diffuse away further as they are not used immediately (i.e. $>1$ doubling times between production and consumption of by-product). We assume this local effect proportionally increases producer uptake (and therefore growth) rates. For universal model assumptions, see table 1. 


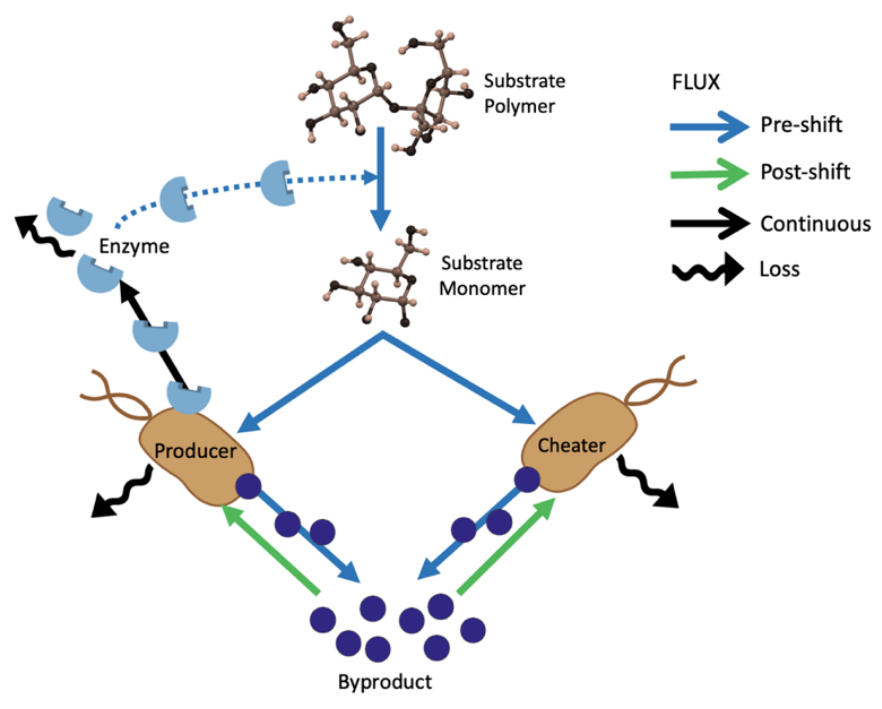

Figure 1. A conceptual diagram of the proposed model. The mass, upon periodic addition as an unavailable polymer, gets bio-transformed as it flows through the system. Some mass gets lost due to thermodynamics and cell mortality (see 'loss' arrows). Pre-shift versus postshift fluxes are mutually exclusive (i.e. cannot happen simultaneously), whereas loss and enzyme synthesis fluxes happen continuously (i.e. regardless of growth substrate used).

175 The following coupled ODEs describe the dynamics in our system:

(1) $\frac{d S}{d t}=S_{\max }-\frac{V_{\max } E S}{K_{m}+S}$

(2) $\frac{d M}{d t}=\frac{V_{\max } E S}{K_{m}+S}-r_{M} C\left(1-\left(\frac{C+P}{K}\right)\right)-r_{M} \varphi P\left(1-\left(\frac{C+P}{K}\right)\right)$

(3) $\frac{d C}{d t}=\left(r_{M} \delta_{M} C+\delta_{b}\left(\frac{C r_{b} e^{-C r_{b}((\alpha+\theta)-t)}}{e^{-C r_{b}((\alpha+\theta)-t)}+1}\right)\right)\left(1-\left(\frac{C+P}{K}\right)\right)-m C$

(4) $\frac{d P}{d t}=\left(r_{M} \varphi \delta_{M} P+\delta_{b}\left(\frac{P r_{b} e^{-P r_{b}(\alpha-t)}}{e^{-P r_{b}(\alpha-t)}+1}\right)\right)\left(1-\left(\frac{C+P}{K}\right)\right)-m P-\gamma P\left(1-\left(\frac{C+P}{K}\right)\right)$

180

(5) $\frac{d E}{d t}=\gamma P\left(1-\left(\frac{C+P}{K}\right)\right)-\beta E$

(6) $\frac{d B}{d t}=\left(\rho\left(r_{M} C+r_{M} \varphi P\right)-\left(\frac{C r_{b} e^{-C r_{b}((\alpha+\theta)-t)}}{e^{-C r_{b}((\alpha+\theta)-t)}+1}\right)-\left(\frac{P r_{b} e^{-P r_{b}(\alpha-t)}}{e^{-P r_{b}(\alpha-t)}+1}\right)\right)\left(1-\left(\frac{C+P}{K}\right)\right)$ 


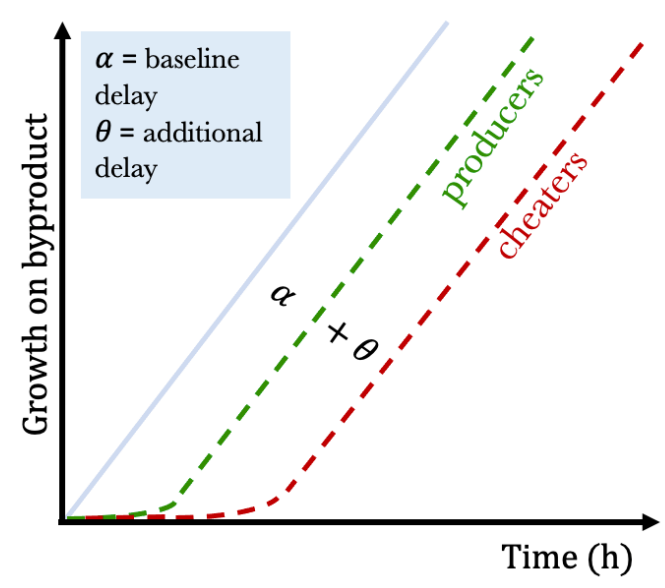

Figure 2. Conceptual graph showing the delay the cheaters and the producers experience when switching to growth on the by-product. The greater the growth rate coefficients, $r_{b}$ (uptake rate) and $\delta_{b}$ (cell yield), the steeper the growth curves. Without any delay, we assume the per capita uptake rate and therefore growth (since the cell yield coefficient is constant) is a linear function of by-product availability. With delay, we assume an expo-linear growth curve instead, where the maximum linear per capita growth rate is initiated after a determined delay period (Goudriaan \& Monteith, 1990). The bigger $\alpha$, the longer the delay for growth on byproduct. For cheaters, this delay is longer (dictated by magnitude of $\theta$ ).

\section{Model analysis}

Assuming constant primary substrate and monomer availability (i.e. no diauxic shift), and no carrying capacity, our system's Jacobian can be reduced to:

$$
\text { (7) } \mathcal{J}(C, P)=\left[\begin{array}{cc}
r_{M} \delta_{M}-m & 0 \\
0 & r_{M} \varphi \delta_{M}-m-\gamma
\end{array}\right]
$$

This leads to the following condition, exclusively reliant on a local benefit effect, in which producers cannot be outcompeted by cheaters (with all parameters $>0$ and $r_{M}, \delta_{M} \& m$ being equal for both cell types):

$$
\text { (8) } \varphi \geq 1+\frac{\gamma}{r_{M} \delta_{M}}
$$

To investigate the effect of substrate availability dynamics, we performed numerical simulation 195 experiments on the model with constant parameter values (see Methods). We performed two modelling experiments to identify qualitative behaviour of cheater-producer dynamics under serial batch culture conditions, replacing half of the volume with fresh medium at each addition 
event (simulating periodicities where dilution is not faster than growth). In the first model experiment, we simulate along a range of periodicity and additional delay values, and we assume there to be no local effect that benefits producers $(\varphi=1)$. In the second simulation experiment, we additionally consider that the spatial/structural heterogeneity in the environment is such that producers experience local benefit effect $(\varphi>1)$. A local sensitivity analysis was executed for parameters within their defined biological range (see table 2) for various periodicity regimes $(6 \mathrm{~h}, 12 \mathrm{~h}, 24 \mathrm{~h})$, assuming intermediate strength of the local benefit effect $(\varphi=1.3)$ and estimated additional delay $(\theta=3)$. The sensitivity was measured for time until the take-over event (where $C>P$ ). Since the model output can represent three qualitatively different trajectories, namely: 1) take-over followed by system collapse, 2) no take-over and continued producer stability (i.e. stable cheater suppression, and 3) no takeover and system collapse (i.e. extinction of producer before cheater can take over), we defined

210 the local sensitivity of our model to each of the parameters by assessing whether the model output is qualitatively different between the two extremities of the defined parameter value range. The sensitivity analysis results shows that the sensitivity of the model output to each individual parameter is primarily dependent on the primary substrate regime. For example, in long periodicities (24h), producers benefit from a higher mortality rate, whereas in intermediate periodicities $(12 \mathrm{~h})$ this same mortality rate leads to cheater take-over and collapse (Table 3 ). 


\section{Results}

In the absence of a speed-agility trade-off faced by cheater cells $(\theta=0)$, and/or a local benefit enjoyed by cooperative producer cells $(\varphi=1)$, a small subgroup of cheater mutant cells is bound to outcompete producer cells, regardless of periodicity of primary substrate (see panel A in figure 4). Collapse of the system follows after cheaters take over, which is in line with in silico (Szilágyi et al., 2017), as well as in vitro findings (Allison et al., 2014). Figure 3 shows a simulation example of such a takeover event.
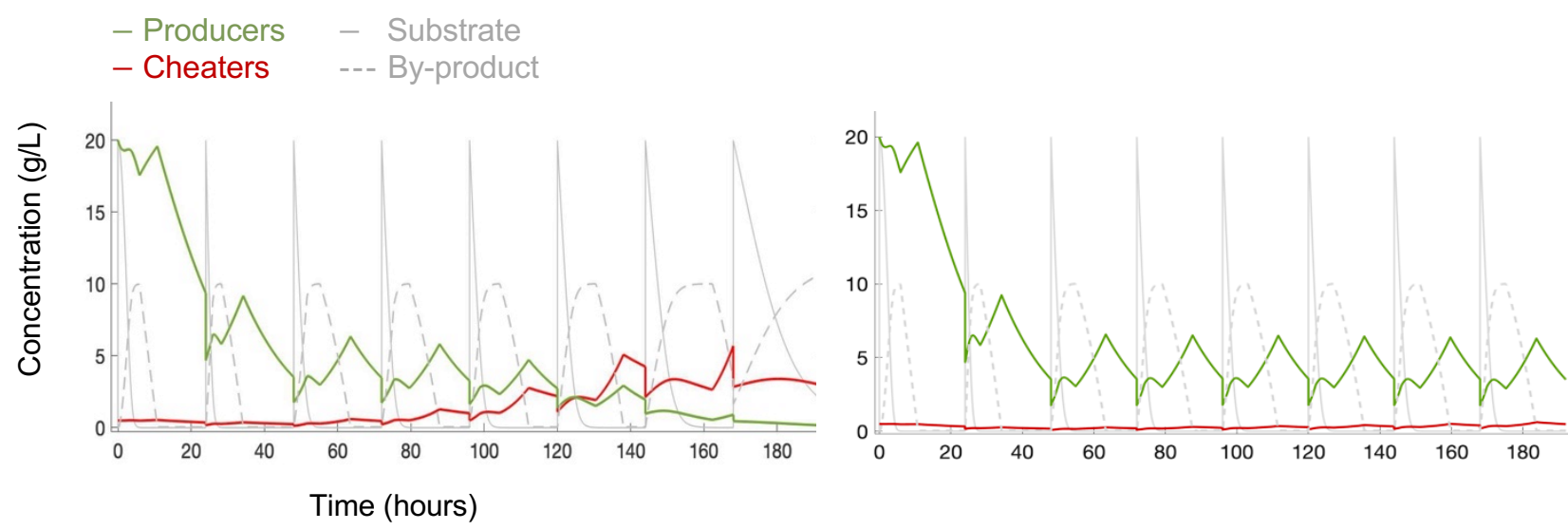

Figure 3. Left: simulation without any cheater-negating mechanisms. Cheaters take over after a few substrate additions (in intervals of $24 \mathrm{~h}$ ), followed by system collapse. Right: example of system stability with cheater-negating mechanisms switched on. Cheaters do not take over, and producer populations remain stable.

Yet, with an additional delay experienced by the cheaters and/or with a local benefit effect for producers, cheater proliferation is no longer the inevitable outcome. The model output predicts the presence of a realm of system stability, which expands with length of additional delay and strength of the local benefit effect, where the pulse interval is neither too short nor too long. When too short, a diauxic shift never occurs. In this realm, cheaters can exercise their competitive benefit over the primary substrate continuously, without suffering the consequences of a delayed growth on the secondary substrate (rendering the amount of additional delay irrelevant). However, the local benefit effect, if available, can erode the cheater's competitive overhand in this regime.

When the period between substrate additions is too long, both substrates can get exhausted within one cycle, after which the producers can no longer offset the costs of producing enzymes with the benefit in growth experienced on the by-product, leading to a realm where cheaters outcompete producers again. Yet, in the intermediate periodicity regimes, an 
additional delay in combination with a local benefit effect can maintain system stability and supress cheaters from taking over. In this regime, either mechanism alone would lead to collapse suggesting a synergy between the two cheater-negating mechanisms.

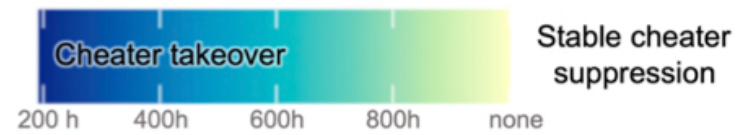

A. No local effect (i.e. well-mixed conditions)

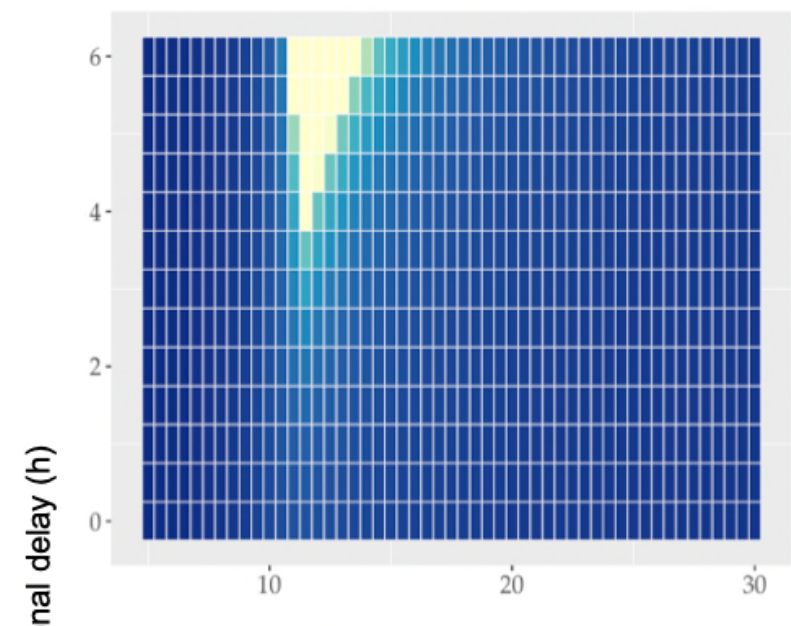

C. Intermediate local effect

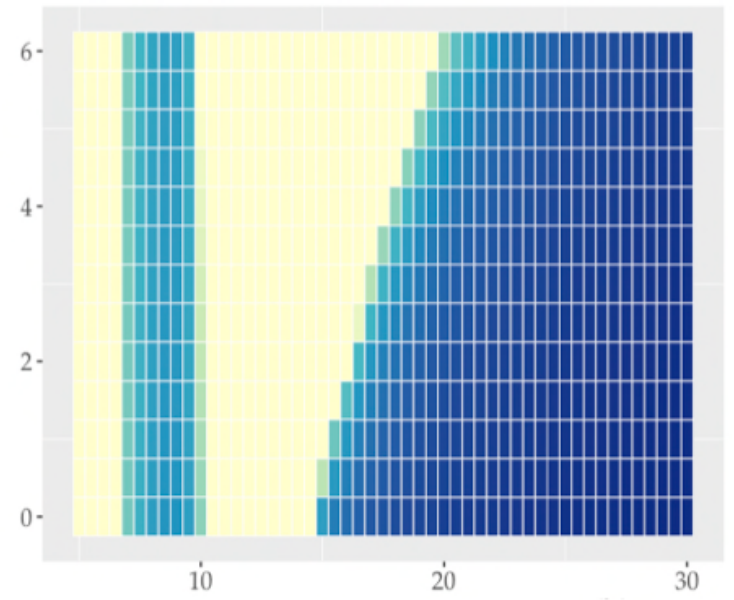

B. Small local effect

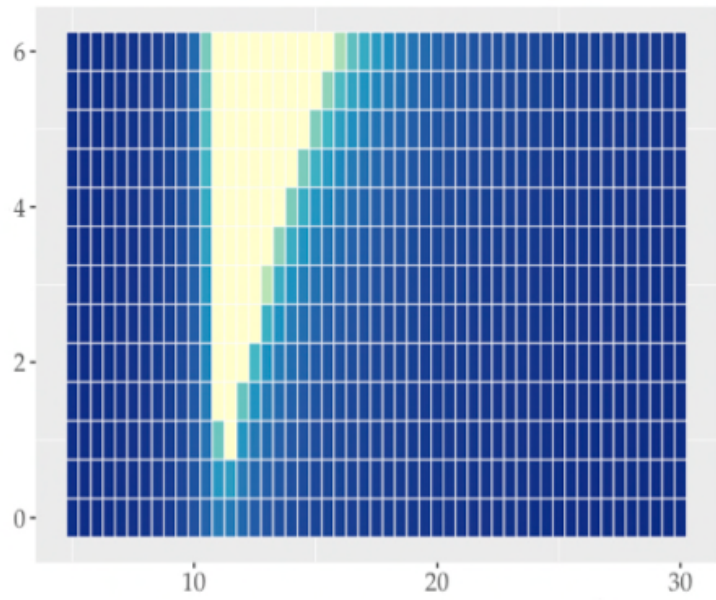

D. Strong local effect

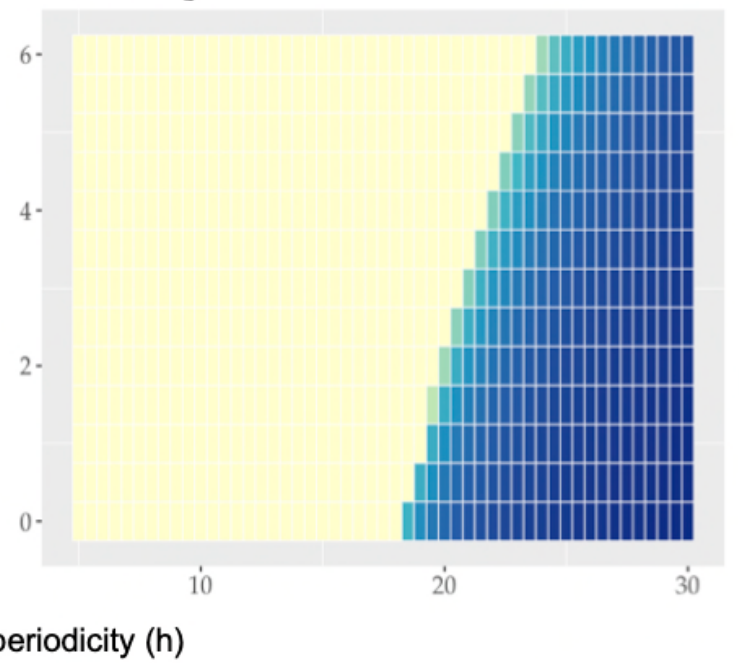

Figure 4. Model solutions along a range of periodicity $(5-30 \mathrm{~h})$ and additional delay values $(0$ $-6 \mathrm{~h}$ ). Solutions predict a realm of system stability (i.e. cheater suppression) along periodicity regimes, which expands with the strength of the speed-agility trade-off (i.e. the length of additional delay) and strength of the local benefit effect (which increases from panel $A$ to $D$ ). 


\section{Discussion \& Conclusion}

250 In this study, we aimed to elucidate in silico that the selective benefit of the cheater strategy in microbial public goods systems depends not only on the cheater's relative advantage over cooperators (i.e. the costs associated with the production of the public good that cheaters defect on), but also on (spatio-) temporal characteristics of the system, subjecting cells that are defecting or about to defect to a more complex selective landscape limiting their real-life occurrence: the 'Cheater's Dilemma'. More specifically, we investigated the Cheater's Dilemma in the context of diauxic shifts. We examined the impact of the availability dynamics of the primary substrate (that is hydrolysed and made available by the public good) on the cheater's ability to outcompete non-cheaters, taking into account two cheater-proliferation negating mechanisms: a speed-agility trade-off for cheater cells - which is grounded on first

260 principles and recent experimental observations (Basan et al., 2020; Fuentes et al., 2021; New et al., 2014) - and a local growth benefit for cooperative (producer) cells.

Our mathematical model suggests that a speed-agility trade-off can make an appreciable difference to the community stability in the wake of cheaters. The identified temporal complexity, namely the interaction between the nutrient periodicity regime and the speedagility trade-off, may constrain cheater mutants from proliferating regardless of their competitive benefit, which would be overlooked in a single regime of substrate availability and diauxic delay.

270 The proposed mechanism of the speed-agility trade-off can work synergistically with other cheater-negating mechanisms; for example with the local benefit effect, as we showed. This synergy can expand the range of conditions under which the system is stable wherein either mechanism alone would lead to system collapse. Accounting for multiple cheater-negating mechanisms will therefore be important to identify critical transitions in fluctuating 275 environments with cheater emergence (Scheffer et al., 2012). Since our model is not spatially explicit, we incorporated the local benefit effect via the simplified alternative of a parameter. However, as argued by Allen et al. (2013), such a parameter is limited in the extent to which it is reflective of true (and variable) local effects experienced by cells, such as colony geometry and spatial diffusion. For the purpose of this study - namely qualitatively demonstrating

280 whether and to which extent the two studied mechanisms have the potential to limit cheater proliferation in the context of diauxic shifts and substrate periodicity - we consider the simplification to be justified.

A possible limitation to our model is that it assumes periodicity of substrate additions that is 285 fixed and not at all stochastic, which could have evolutionary consequences (see Levins 
(2020); Mitchell et al. (2009)), for instance in duration of lag phase (hu \& Barnes, 2016). However, for many natural systems, such pulsation of carbon additions is regular and at most stochastic within a limited range of this regularity, and hence, one may expect the possible role of stochasticity to be of limited relevance to the predicted qualitative behaviour of the modelled cheater - producer dynamics. Having modelled such stochasticity (by drawing a random number within a defined range for each substrate addition), the qualitative behaviour of the model remains practically identical (see supplement $\mathrm{C}-\mathrm{E}$ ).

In the realm of longer pulse intervals, where the speed-agility trade-off comes into effect,

295 producer stability is maintained via a process akin to the Snowdrift game, facilitating coexistence rather than full extinction of the cheater cells (in line with Xenophontos et al. (2021)). In this realm, shorter diauxic delay times provide a selective benefit to producer cells. Additionally, in the realm of very long pulse intervals (with imminent substrate exhaustion), one may expect a selective pressure towards evolving optimality in regulation of enzyme

300 production, not only in the (empirically identified) upper limit of substrate concentration (Dueñas-Sánchez et al., 2012), but also in the lower limit, allowing producers a level playing field in periods of starvation. This lower limit of the primary substrate concentration could also serve as a signal in asymmetric anticipatory regulation of the diauxic shift, optimising the delay period in periodicity realms where pulsations are long (Mitchell et al., 2009). Having modelled

305 such conditional enzyme investment, we still see similar qualitative behaviour of our model, generating a realm of stability that expands with the additional delay period (see supplement A).

In conclusion, our results highlight the need to study cheater dynamics in a more complex

310 (temporal) dynamic landscape, and call for future studies (in vitro and in silico alike) to take nutrient periodicity and the speed-agility trade-off into account when mapping the potential proliferation of (microbial) cheater mutants in fluctuating environments, such as the gut.

\section{Methods}

315 Numerical simulations were executed using the 'ode45' function in MATLAB (R2021a). Heatmaps of model output were generated using the 'ggplot2' package in RStudio (Version 1.3.1093).

\section{Acknowledgements}

320 We thank Anna Lindell for providing parts of the illustrations used in this study. This project has received funding from the European Research Council (ERC) under the European Union's Horizon 2020 research and innovation programme (Grant agreement No. 866028). 


\section{Author contribution}

N.I.v.d.B. and K.R.P. conceived the project and wrote the manuscript. N.I.v.d.B. and L.K. performed the model simulations. All contributed to data interpretation.

\section{References}

Allen, B., Gore, J., \& Nowak, M. A. (2013). Spatial dilemmas of diffusible public goods. Elife, 2, e01169. https://doi.org/10.7554/eLife.01169

330 Allison, S. D., Lu, L., Kent, A. G., \& Martiny, A. C. (2014). Extracellular enzyme production and cheating in Pseudomonas fluorescens depend on diffusion rates. Frontiers in microbiology, 5, 169. https://doi.org/10.3389/fmicb.2014.00169

Atiyeh, H., \& Duvnjak, Z. (2002). Production of fructose and ethanol from sugar beet molasses using Saccharomyces cerevisiae ATCC 36858. Biotechnology progress, 18(2), 234-239.

335 https://doi.org/10.1021/bp010164z

Bachmann, H., Fischlechner, M., Rabbers, I., Barfa, N., dos Santos, F. B., Molenaar, D., \& Teusink, B. (2013). Availability of public goods shapes the evolution of competing metabolic strategies. Proceedings of the National Academy of Sciences, 110(35), 14302-14307. https://doi.org/10.1073/pnas.1308523110

340 Basan, M., Honda, T., Christodoulou, D., Hörl, M., Chang, Y.-F., Leoncini, E., Mukherjee, A., Okano, H., Taylor, B. R., \& Silverman, J. M. (2020). A universal trade-off between growth and lag in fluctuating environments. Nature, 584(7821), 470-474. https://doi.org/10.1038/s41586-020$2505-4$

Bassetti, F., Bergamasco, R., Moraes, F., \& Zanin, G. (2000). Thermal stability and deactivation energy of free and immobilized invertase. Brazilian Journal of Chemical Engineering, 17(4-7), 867-872. https://doi.org/10.1590/S0104-66322000000400050

Basso, T. O., de Kok, S., Dario, M., do Espirito-Santo, J. C. A., Müller, G., Schlölg, P. S., Silva, C. P., Tonso, A., Daran, J.-M., \& Gombert, A. K. (2011). Engineering topology and kinetics of sucrose metabolism in Saccharomyces cerevisiae for improved ethanol yield. Metabolic engineering, 13(6), 694-703. https://doi.org/10.1016/j.ymben.2011.09.005

Bastiaans, E., Debets, A. J., \& Aanen, D. K. (2016). Experimental evolution reveals that high relatedness protects multicellular cooperation from cheaters. Nature communications, 7(1), 1 10. https://doi.org/10.1038/ncomms11435

Berthrong, S. T., Buckley, D. H., \& Drinkwater, L. E. (2013). Agricultural management and labile carbon additions affect soil microbial community structure and interact with carbon and nitrogen cycling. Microbial ecology, 66(1), 158-170. https://doi.org/10.1007/s00248-013-0225$\underline{0}$

Blasche, S., Kim, Y., Mars, R. A., Machado, D., Maansson, M., Kafkia, E., Milanese, A., Zeller, G., Teusink, B., \& Nielsen, J. (2021). Metabolic cooperation and spatiotemporal niche partitioning in a kefir microbial community. Nature Microbiology, 6(2), 196-208. https://doi.org/10.1038/s41564-020-00816-5

Brejning, J., \& Jespersen, L. (2002). Protein expression during lag phase and growth initiation in Saccharomyces cerevisiae. International journal of food microbiology, 75(1-2), 27-38. https://doi.org/10.1016/S0168-1605(01)00726-7

365 Carrero-Colón, M., Nakatsu, C. H., \& Konopka, A. (2006). Effect of nutrient periodicity on microbial community dynamics. Applied and environmental microbiology, 72(5), 3175-3183. https://doi.org/10.1128/AEM.72.5.3175-3183.2006

Cavaliere, M., Feng, S., Soyer, O. S., \& Jiménez, J. I. (2017). Cooperation in microbial communities and their biotechnological applications. Environmental microbiology, 19(8), 2949-2963.

$370 \quad$ https://doi.org/10.1111/1462-2920.13767

Chen, A., Sanchez, A., Dai, L., \& Gore, J. (2014). Dynamics of a producer-freeloader ecosystem on the brink of collapse. Nature communications, 5(1), 1-6. https://doi.org/10.1038/ncomms4713

Christiansen, T., \& Nielsen, J. (2002). Production of extracellular protease and glucose uptake in Bacillus clausii in steady-state and transient continuous cultures. Journal of biotechnology, 97(3), 265-273. https://doi.org/10.1016/S0168-1656(02)00109-8

Chu, D., \& Barnes, D. J. (2016). The lag-phase during diauxic growth is a trade-off between fast adaptation and high growth rate. Scientific reports, 6(1), 1-15.

https://doi.org/10.1038/srep25191 
Chuang, J. S., Rivoire, O., \& Leibler, S. (2009). Simpson's paradox in a synthetic microbial system. Science, 323(5911), 272-275. https://doi.org/10.1126/science.1166739

Cremer, J., Melbinger, A., \& Frey, E. (2012). Growth dynamics and the evolution of cooperation in microbial populations. Scientific reports, 2(1), 1-6. https://doi.org/10.1038/srep00281

Dennehy, J. J., \& Turner, P. E. (2004). Reduced fecundity is the cost of cheating in RNA virus $\varphi 6$. Proceedings of the Royal Society of London. Series B: Biological Sciences, 271(1554), 2275-

385 2282. https://doi.org/10.1098/rspb.2004.2833

Dobay, A., Bagheri, H. C., Messina, A., Kümmerli, R., \& Rankin, D. (2014). Interaction effects of cell diffusion, cell density and public goods properties on the evolution of cooperation in digital microbes. Journal of evolutionary biology, 27(9), 1869-1877. https://doi.org/10.1111/jeb.12437

Dueñas-Sánchez, R., Gutiérrez, G., Rincón, A. M., Codón, A. C., \& Benítez, T. (2012). Transcriptional regulation of fermentative and respiratory metabolism in Saccharomyces cerevisiae industrial bakers' strains. FEMS yeast research, 12(6), 625-636. https://doi.org/10.1111/i.15671364.2012.00813.X

Dumas, Z., \& Kummerli, R. (2012). Cost of cooperation rules selection for cheats in bacterial metapopulations. J Evol Biol, 25(3), 473-484. https://doi.org/10.1111/j.1420-

$395 \quad$ 9101.2011.02437.x

Espinosa Vidal, E., de Morais Jr, M. A., François, J. M., \& de Billerbeck, G. M. (2015). Biosynthesis of higher alcohol flavour compounds by the yeast Saccharomyces cerevisiae: impact of oxygen availability and responses to glucose pulse in minimal growth medium with leucine as sole nitrogen source. Yeast, 32(1), 47-56. https://doi.org/10.1002/yea.3045

400 Essel, K. K., \& Osei, Y. D. (2014). Investigation of some kinetic properties of commercial invertase from yeast. Nat Prod Chem Res, 2(152). https://doi.org/10.4172/2329-6836.1000152

Estrela, S., Sanchez-Gorostiaga, A., Vila, J. C., \& Sanchez, A. (2021). Nutrient dominance governs the assembly of microbial communities in mixed nutrient environments. Elife, 10. https://doi.org/10.7554/eLife.65948

405 Estrela, S., Vila, J. C., Lu, N., Bajic, D., Rebolleda-Gomez, M., Chang, C.-Y., \& Sanchez, A. (2020). Metabolic rules of microbial community assembly. bioRxiv. https://doi.org/10.1101/2020.03.09.984278

Fiegna, F., \& Velicer, G. J. (2003). Competitive fates of bacterial social parasites: persistence and self-induced extinction of Myxococcus xanthus cheaters. Proc Biol Sci, 270(1523), 1527-

\section{1534. https://doi.org/10.1098/rspb.2003.2387}

Figueiredo, A. R., Wagner, A., \& Kümmerli, R. (2021). Ecology drives the evolution of diverse siderophore-production strategies in the opportunistic human pathogen Pseudomonas aeruginosa. bioRxiv. https://doi.org/10.1101/2021.01.27.427959

415 microbes: social evolution and nutrient depolymerization rates. Frontiers in microbiology, 3 , 338. https://doi.org/10.3389/fmicb.2012.00338

Foster, K. R., Shaulsky, G., Strassmann, J. E., Queller, D. C., \& Thompson, C. R. (2004). Pleiotropy as a mechanism to stabilize cooperation. Nature, 431(7009), 693-696. https://doi.org/10.1038/nature02894

420 Francesca, G., Francesca, M., Tania, G., Marina, B., Maurizio, S., \& Alessandra, M. (2010). Effect of different glucose concentrations on proteome of Saccharomyces cerevisiae. Biochimica et Biophysica Acta (BBA)-Proteins and Proteomics, 1804(7), 1516-1525. https://doi.org/10.1016/j.bbapap.2010.03.008

Frank, S. A. (2010). Microbial secretor-cheater dynamics. Philosophical Transactions of the Royal
Society B: Biological Sciences, 365(1552), 2515-2522. https://doi.org/10.1098/rstb.2010.0003

Fuentes, D. A. F., Manfredi, P., Jenal, U., \& Zampieri, M. (2021). Pareto optimality between growthrate and lag-time couples metabolic noise to phenotypic heterogeneity in Escherichia coli. Nature communications, 12(1), 3204. https://doi.org/10.1038/s41467-021-23522-0

$430 \quad$ Evolution, 68(2), 318-331. https://doi.org/10.1111/evo.12266

Gibb, E. H. (2018). Understanding the diauxic shift in Saccharomyces cerevisiae and its evolutionarily conserved mechanisms of regulation. University of California, Merced.

Gilbert, O. M., Foster, K. R., Mehdiabadi, N. J., Strassmann, J. E., \& Queller, D. C. (2007). High relatedness maintains multicellular cooperation in a social amoeba by controlling cheater mutants. Proceedings of the National Academy of Sciences, 104(21), 8913-8917. https://doi.org/10.1073/pnas.0702723104 
Giuseppin, M., Almkerk, J., Heistek, J., \& Verrips, C. (1993). Comparative study on the production of guar alpha-galactosidase by Saccharomyces cerevisiae SU50B and Hansenula polymorpha $8 / 2$ in continuous cultures. Applied and environmental microbiology, 59(1), 52-59.

440 Goldford, J. E., Lu, N., Bajic, D., Estrela, S., Tikhonov, M., Sanchez-Gorostiaga, A., Segre, D., Mehta, P., \& Sanchez, A. (2018). Emergent simplicity in microbial community assembly. Science, 361(6401), 469-474. https://doi.org/10.1126/science.aat1168

Gore, J., Youk, H., \& van Oudenaarden, A. (2009). Snowdrift game dynamics and facultative cheating in yeast. Nature, 459(7244), 253-256. https://doi.org/10.1038/nature07921

445 Goudriaan, J., \& Monteith, J. (1990). A mathematical function for crop growth based on light interception and leaf area expansion. Annals of Botany, 66(6), 695-701. https://doi.org/10.1093/oxfordjournals.aob.a088084

Greig, D., \& Travisano, M. (2004). The Prisoner's Dilemma and polymorphism in yeast SUC genes. Proc Biol Sci, 271 Suppl 3, S25-26. https://doi.org/10.1098/rsbl.2003.0083

450 Haurie, V., Boucherie, H., \& Sagliocco, F. (2003). The Snf1 protein kinase controls the induction of genes of the iron uptake pathway at the diauxic shift in Saccharomyces cerevisiae. J Biol Chem, 278(46), 45391-45396. https://doi.org/10.1074/jbc.M307447200

Ho, H. I., Hirose, S., Kuspa, A., \& Shaulsky, G. (2013). Kin recognition protects cooperators against cheaters. Curr Biol, 23(16), 1590-1595. https://doi.org/10.1016/i.cub.2013.06.049

455 Jones, K. D., \& Kompala, D. S. (1999). Cybernetic model of the growth dynamics of Saccharomyces cerevisiae in batch and continuous cultures. J Biotechnol, 71(1-3), 105-131. https://doi.org/10.1016/s0168-1656(99)00017-6

Kim, J., Darlington, A., Salvador, M., Utrilla, J., \& Jiménez, J. I. (2020). Trade-offs between gene expression, growth and phenotypic diversity in microbial populations. Current opinion in

460 biotechnology, 62, 29-37. https://doi.org/10.1016/i.copbio.2019.08.004

Koch, A. L. (1971). The adaptive responses of Escherichia coli to a feast and famine existence. In Advances in microbial physiology (Vol. 6, pp. 147-217). Elsevier. https://doi.org/10.1016/S0065-2911(08)60069-7

Konopka, A., Carrero-Colon, M., \& Nakatsu, C. H. (2007). Community dynamics and heterogeneities in mixed bacterial communities subjected to nutrient periodicities. Environmental microbiology, 9(6), 1584-1590. https://doi.org/10.1111/j.1462-2920.2007.01326.x

Koschwanez, J. H., Foster, K. R., \& Murray, A. W. (2011). Sucrose utilization in budding yeast as a model for the origin of undifferentiated multicellularity. PLoS Biol, 9(8), e1001122. https://doi.org/10.1371/journal.pbio.1001122

470 Kremling, A., Geiselmann, J., Ropers, D., \& de Jong, H. (2018). An ensemble of mathematical models showing diauxic growth behaviour. BMC systems biology, 12(1), 1-16. https://doi.org/10.1186/s12918-018-0604-8

Kümmerli, R., Gardner, A., West, S. A., \& Griffin, A. S. (2009). Limited dispersal, budding dispersal, and cooperation: an experimental study. Evolution: International Journal of Organic Evolution,

475 63(4), 939-949. https://doi.org/10.1111/j.1558-5646.2008.00548.x

Kümmerli, R., Santorelli, L. A., Granato, E. T., Dumas, Z., Dobay, A., Griffin, A. S., \& West, S. A. (2015). Co-evolutionary dynamics between public good producers and cheats in the bacterium Pseudomonas aeruginosa. Journal of evolutionary biology, 28(12), 2264-2274. https://doi.org/10.1111/jeb.12751

480 Kuzdzal-Fick, J. J., Fox, S. A., Strassmann, J. E., \& Queller, D. C. (2011). High relatedness is necessary and sufficient to maintain multicellularity in Dictyostelium. Science, 334(6062), 1548-1551. https://doi.org/10.1126/science.1213272

Levins, R. (2020). Evolution in changing environments. Princeton University Press.

Lewis, J., Northcott, C., Learmonth, R., Attfield, P., \& Watson, K. (1993). The need for consistent nomenclature and assessment of growth phases in diauxic cultures of Saccharomyces cerevisiae. Microbiology, 139(4), 835-839. https://doi.org/10.1099/00221287-139-4-835

MacLean, R. C., \& Gudelj, I. (2006). Resource competition and social conflict in experimental populations of yeast. Nature, 441(7092), 498-501. https://doi.org/10.1038/nature04624

Madgwick, P. G., Stewart, B., Belcher, L. J., Thompson, C. R., \& Wolf, J. B. (2018). Strategic investment explains patterns of cooperation and cheating in a microbe. Proceedings of the National Academy of Sciences, 115(21), E4823-E4832. https://doi.org/10.1073/pnas.1716087115

Malairuang, K., Krajang, M., Sukna, J., Rattanapradit, K., \& Chamsart, S. (2020). High Cell Density Cultivation of Saccharomyces cerevisiae with Intensive Multiple Sequential Batches Together with a Novel Technique of Fed-Batch at Cell Level (FBC). Processes, 8(10), 1321. https://doi.org/10.3390/pr8101321 
Marques, W. L., Raghavendran, V., Stambuk, B. U., \& Gombert, A. K. (2016). Sucrose and Saccharomyces cerevisiae: a relationship most sweet. FEMS yeast research, 16(1). https://doi.org/10.1093/femsyr/fov107

500 Mitchell, A., Romano, G. H., Groisman, B., Yona, A., Dekel, E., Kupiec, M., Dahan, O., \& Pilpel, Y. (2009). Adaptive prediction of environmental changes by microorganisms. Nature, 460(7252), 220-224. https://doi.org/10.1038/nature08112

Momeni, B., Waite, A. J., \& Shou, W. (2013). Spatial self-organization favors heterotypic cooperation over cheating. Elife, 2, e00960. https://doi.org/10.7554/eLife.00960.001

505 Nadell, C. D., Xavier, J. B., \& Foster, K. R. (2009). The sociobiology of biofilms. FEMS Microbiol Rev, 33(1), 206-224. https://doi.org/10.1111//.1574-6976.2008.00150.x

New, A. M., Cerulus, B., Govers, S. K., Perez-Samper, G., Zhu, B., Boogmans, S., Xavier, J. B., \& Verstrepen, K. J. (2014). Different levels of catabolite repression optimize growth in stable and variable environments. PLoS Biol, 12(1), e1001764.

$510 \quad$ https://doi.org/10.1371/journal.pbio.1001764

Oliveira, N. M., Niehus, R., \& Foster, K. R. (2014). Evolutionary limits to cooperation in microbial communities. Proc Natl Acad Sci U S A, 111(50), 17941-17946. https://doi.org/10.1073/pnas.1412673111

515 promote species coexistence in competitive microbial communities. PLoS Comput Biol, 16(5), e1007896. https://doi.org/10.1371/journal.pcbi.1007896

Pudlo, N. A., Urs, K., Kumar, S. S., German, J. B., Mills, D. A., \& Martens, E. C. (2015). Symbiotic human gut bacteria with variable metabolic priorities for host mucosal glycans. Mbio, 6(6). https://doi.org/10.1128/mBio.01282-15

520 Rainey, P. B., \& Rainey, K. (2003). Evolution of cooperation and conflict in experimental bacterial populations. Nature, 425(6953), 72-74. https://doi.org/10.1038/nature01942

Ramin, K. I., \& Allison, S. D. (2019). Bacterial tradeoffs in growth rate and extracellular enzymes. Frontiers in microbiology, 10, 2956. https://doi.org/10.3389/fmicb.2019.02956

Rankin, D. J., Bargum, K., \& Kokko, H. (2007). The tragedy of the commons in evolutionary biology. Trends in ecology \& evolution, 22(12), 643-651. https://doi.org/10.1016/j.tree.2007.07.009

Raymond, B., West, S. A., Griffin, A. S., \& Bonsall, M. B. (2012). The dynamics of cooperative bacterial virulence in the field. Science, 337(6090), 85-88. https://doi.org/10.1126/science.1218196

Ronen, M., \& Botstein, D. (2006). Transcriptional response of steady-state yeast cultures to transient perturbations in carbon source. Proc Natl Acad Sci U S A, 103(2), 389-394. https://doi.org/10.1073/pnas.0509978103

Ross-Gillespie, A., Gardner, A., West, S. A., \& Griffin, A. S. (2007). Frequency dependence and cooperation: theory and a test with bacteria. The American Naturalist, 170(3), 331-342. https://doi.org/10.1086/519860

535 Salvy, P., \& Hatzimanikatis, V. (2021). Emergence of diauxie as an optimal growth strategy under resource allocation constraints in cellular metabolism. Proceedings of the National Academy of Sciences, 118(8). https://doi.org/10.1073/pnas.2013836118

Scheffer, M., Carpenter, S. R., Lenton, T. M., Bascompte, J., Brock, W., Dakos, V., Van de Koppel, J., Van de Leemput, I. A., Levin, S. A., \& Van Nes, E. H. (2012). Anticipating critical transitions.

540 Science, 338(6105), 344-348. https://doi.org/10.1126/science.1225244 competition. The ISME journal, 9(1), 139-149. https://doi.org/10.1038/ismej.2014.174

Schuster, M., Foxall, E., Finch, D., Smith, H., \& De Leenheer, P. (2017). Tragedy of the commons in the chemostat. PloS one, 12(12), e0186119. https://doi.org/10.1371/journal.pone.0186119

545 Shou, W., Ram, S., \& Vilar, J. M. (2007). Synthetic cooperation in engineered yeast populations. Proceedings of the National Academy of Sciences, 104(6), 1877-1882. https://doi.org/10.1073/pnas.0610575104

Smith, J., Van Dyken, J. D., \& Velicer, G. J. (2014). Nonadaptive processes can create the appearance of facultative cheating in microbes. Evolution, 68(3), 816-826.

$550 \quad$ https://doi.org/10.1111/evo.12306

Smukalla, S., Caldara, M., Pochet, N., Beauvais, A., Guadagnini, S., Yan, C., Vinces, M. D., Jansen, A., Prevost, M. C., \& Latgé, J.-P. (2008). FLO1 is a variable green beard gene that drives biofilm-like cooperation in budding yeast. Cell, 135(4), 726-737.

https://doi.org/10.1016/j.cell.2008.09.037 
555 Solopova, A., van Gestel, J., Weissing, F. J., Bachmann, H., Teusink, B., Kok, J., \& Kuipers, O. P. (2014). Bet-hedging during bacterial diauxic shift. Proceedings of the National Academy of Sciences, 111(20), 7427-7432. https://doi.org/10.1073/pnas.1320063111

Strassmann, J. E., \& Queller, D. C. (2011). Evolution of cooperation and control of cheating in a social microbe. Proceedings of the National Academy of Sciences, 108(Supplement 2), 1085510862. https://doi.org/10.1073/pnas.1102451108

Stump, S. M., Johnson, E. C., \& Klausmeier, C. A. (2018). Local interactions and self-organized spatial patterns stabilize microbial cross-feeding against cheaters. Journal of the Royal Society Interface, 15(140), 20170822. https://doi.org/10.1098/rsif.2017.0822

Szilágyi, A., Boza, G., \& Scheuring, I. (2017). Analysis of stability to cheaters in models of antibiotic degrading microbial communities. Journal of theoretical biology, 423, 53-62. https://doi.org/10.1016/i.jtbi.2017.04.025

Taherzadeh, M. J., Niklasson, C., \& Lidén, G. (1997). Acetic acid-friend or foe in anaerobic batch conversion of glucose to ethanol by Saccharomyces cerevisiae? Chemical engineering science, 52(15), 2653-2659. https://doi.org/10.1016/S0009-2509(97)00080-8

Travisano, M., \& Velicer, G. J. (2004). Strategies of microbial cheater control. Trends in microbiology, 12(2), 72-78. https://doi.org/10.1016/i.tim.2003.12.009

van den Brink, J., Pronk, J., de Winde, H., \& Daran-Lapujade, P. (2008). Translation and its ATP costs govern the dynamics of the glucose-galactose diauxic shift in Saccharomyces cerevisiae. Dynamic response of Saccharomyces cerevisiae to fermentative growth conditions.

Van Dyken, J. D., Müller, M. J., Mack, K. M., \& Desai, M. M. (2013). Spatial population expansion promotes the evolution of cooperation in an experimental prisoner's dilemma. Current Biology, 23(10), 919-923. https://doi.org/10.1016/i.cub.2013.04.026

van Tatenhove-Pel, R. J., de Groot, D. H., Bisseswar, A. S., Teusink, B., \& Bachmann, H. (2021). Population dynamics of microbial cross-feeding are determined by co-localization probabilities and cooperation-independent cheater growth. ISME J. https://doi.org/10.1038/s41396-02100986-y

Waite, A. J., \& Shou, W. (2012). Adaptation to a new environment allows cooperators to purge cheaters stochastically. Proceedings of the National Academy of Sciences, 109(47), 1907919086. https://doi.org/10.1073/pnas.1210190109

Westhoek, A., Field, E., Rehling, F., Mulley, G., Webb, I., Poole, P. S., \& Turnbull, L. A. (2017). Policing the legume-Rhizobium symbiosis: a critical test of partner choice. Scientific reports, 7(1), 1-10. https://doi.org/10.1038/s41598-017-01634-2

Xenophontos, C., Harpole, S., Kuesel, K., \& Clark, A. (2021). Coexisting with cheaters: Microbial exoenzyme production as a snowdrift game model. Authorea Preprints. https://doi.org/10.22541/au.161395183.38200120/v1

Yi, X., \& Dean, A. M. (2016). Phenotypic plasticity as an adaptation to a functional trade-off. Elife, 5, e19307. https://doi.org/10.7554/eLife.19307.001 
Table 1. Overview of model assumptions

\begin{tabular}{|c|c|c|}
\hline Assumption & Model implications & Justification \\
\hline $\begin{array}{l}\text { We simplify uptake rates by assuming linear dynamics as a } \\
\text { function of monomer/by-product concentration instead of Monod } \\
\text { dynamics. In this linearised realm of uptake, only by-product } \\
\text { uptake rate operates near maximum velocity. }\end{array}$ & $\begin{array}{l}r_{b} \approx r_{b_{\max }} \\
r_{b} \ll r_{M}<r_{M_{\max }}\end{array}$ & \\
\hline $\begin{array}{l}\text { Both cheaters and producers experience the same linear per } \\
\text { capita uptake rate of the by-product, which commences after an } \\
\text { initial 'baseline' delay. However, cheaters experience an } \\
\text { additional delay since they grow faster on the primary substrate. }\end{array}$ & $\begin{array}{l}\text { Cheater total delay duration is } \\
\text { described by } \alpha+\theta \\
\text { (see figure 2) }\end{array}$ & $\begin{array}{l}\text { Basan et al. } \\
\begin{array}{l}\text { (2020); } \\
\text { al. }\end{array} \text { (2014), } \\
\text { Fuentes et al. } \\
\underline{(2021)} \text {, } \\
\text { Raymond et al. } \\
\underline{(2012),} \text { Ramin } \\
\underline{\text { and }} \text { Allison } \\
\underline{(2019)}\end{array}$ \\
\hline $\begin{array}{l}\text { Growth on the primary substrate continues until its concentration } \\
\text { reaches virtually } 0 \text {, after which the diauxic shift commences }\end{array}$ & $r_{M}=0$ when $M<M_{\text {threshold }}$ & $\underline{\text { Haurie et al. }}$ \\
\hline $\begin{array}{l}\text { By-products continue to accumulate in the system until they start } \\
\text { to be consumed. Consumption halts upon exhaustion. }\end{array}$ & $\begin{array}{l}r_{b}=0 \text { when } M>M_{\text {threshold }} \text { or } \\
B<B_{\text {threshold }}\end{array}$ & $\underline{\text { Haurie et al. }}$ \\
\hline $\begin{array}{l}\text { We assume no conversion of substrate into processed monomer } \\
\text { when the enzyme or the substrate is missing. }\end{array}$ & $\begin{array}{l}\text { Input } M \text { only via Michaelis- } \\
\text { Menten decay of } S \text {. }\end{array}$ & $\underline{\text { Schuster et al. }}$ \\
\hline Cheater mutants cannot regain enzyme-synthesising abilities. & $\begin{array}{l}\gamma=0 \text { for } C \text { throughout simulated } \\
\text { time }\end{array}$ & \\
\hline $\begin{array}{l}\text { The system is constrained by an explicit carrying capacity, } \\
\text { implying competition for space or other limiting resources. }\end{array}$ & $\begin{array}{l}\text { Terms related to mass uptake } \\
\text { and secretion are constrained } \\
\text { as }(C+P) \rightarrow \mathrm{K}\end{array}$ & $\begin{array}{l}\text { Frank (2010); } \\
\text { Smith et al. } \\
\underline{(2014)}\end{array}$ \\
\hline $\begin{array}{l}\text { Local structure allows the grouping together of cells, which } \\
\text { decreases the likelihood of monomers diffusing too far away for } \\
\text { consumption by producers, benefitting producer growth. }\end{array}$ & $\begin{array}{l}\text { A proportionality constant of } \\
\varphi>1 \text { increases } M \text { uptake term } \\
\text { for producers. }\end{array}$ & $\begin{array}{l}\text { Stump et al. } \\
\underline{(2018)}\end{array}$ \\
\hline $\begin{array}{l}\text { The environment (e.g. temperature and } \mathrm{pH} \text { ), other than the } \\
\text { dynamic availability of the primary substrate, is held constant. }\end{array}$ & $\begin{array}{l}\text { Kinetic parameters, } V_{\max } \& K_{m} \\
\text { are constant }\end{array}$ & \\
\hline $\begin{array}{l}\text { Cheater mutants are established and have survived stochastic } \\
\text { extinction. They initially occur in small numbers in an otherwise } \\
\text { stable population of producer cells, to reflect a realistic order of } \\
\text { magnitude of early mutant cell line evolution. }\end{array}$ & $\begin{array}{l}\text { The model is initialised with a } \\
\text { cheater to producer ratio of } \\
\leq 1: 10\end{array}$ & $\begin{array}{l}\text { Ross-Gillespie et } \\
\underline{\text { al. (2007) }}\end{array}$ \\
\hline
\end{tabular}


Table 2. Overview of parameters used in our model

\begin{tabular}{|c|c|c|c|c|}
\hline Parameter & Description & Dimensions & Value & Justification \\
\hline$S_{\max }$ & $\begin{array}{l}\text { Max amount of } \\
\text { substrate added at } \\
\text { each pulse }\end{array}$ & {$\left[g l^{-1}\right][h]^{-1}$} & 20 & $\begin{array}{l}\text { Corresponding to standard medium enrichment of } 2 \% \\
\text { sucrose. Francesca et al. (2010); Van Dyken et al. } \\
\text { (2013). }\end{array}$ \\
\hline$V_{\max }$ & $\begin{array}{l}\text { Maximum reaction } \\
\text { rate enzyme with } \\
\text { substrate }\end{array}$ & {$\left[g^{-1}\right][h]^{-1}$} & 20.5 & $\begin{array}{l}\text { For soluble invertase hydrolysing sucrose at optimum } \\
\mathrm{pH} \text { and temperature, adopted from Essel and Osei } \\
(2014) \text {. Original units: } 1 \mathrm{mM} \mathrm{min}^{-1} \text {. }\end{array}$ \\
\hline$K_{m}$ & $\begin{array}{l}\text { Half-saturation } \\
\text { constant for } \\
\text { substrate decay }\end{array}$ & {$\left[g l^{-1}\right]$} & $\sim 8.2$ & $\begin{array}{l}\text { For soluble invertase hydrolysing sucrose at optimum } \\
\mathrm{pH} \text { and temperature, adopted from Essel and Osei } \\
(2014) \text {. Original units: } 24 \mathrm{mM} \text {. }\end{array}$ \\
\hline$r_{M}$ & $\begin{array}{l}\text { Uptake rate } \\
\text { primary monomer }\end{array}$ & {$\left[g^{-1}\right][h]^{-1}$} & $\sim 2$ & $\begin{array}{l}\text { Assuming a less than maximum growth rate, e.g. } 0.3 \\
\mathrm{~h}^{-1} \text {, the glucose uptake rate becomes } \sim 2 \mathrm{~h}^{-1} \text {. Jones and } \\
\text { Kompala (1999). }\end{array}$ \\
\hline$r_{b}$ & $\begin{array}{l}\text { Uptake rate by- } \\
\text { product }\end{array}$ & {$\left[g l^{-1}\right][h]^{-1}$} & $\sim 0.3$ & $\begin{array}{l}\text { Ethanol uptake rate is around } \sim 0.3 \mathrm{~h}^{-1} \text { (with max } \\
\text { growth rate of } 0.2 \mathrm{~h}^{-1} \text { and cell yield of } 0.65 \text { ). Jones and } \\
\text { Kompala (1999). }\end{array}$ \\
\hline$\delta_{M}$ & $\begin{array}{l}\text { Yield coefficient } \\
\text { primary monomer }\end{array}$ & {$\left[g l^{-1}\right]^{-1}$} & $\sim 0.15$ & $\begin{array}{l}\text { S. cerevisiae growing on glucose. Jones and Kompala } \\
(1999) \text {. }\end{array}$ \\
\hline$\delta_{b}$ & $\begin{array}{l}\text { Yield coefficient by- } \\
\text { product }\end{array}$ & {$\left[g l^{-1}\right]^{-1}$} & $\sim 0.65$ & $\begin{array}{l}\text { S. cerevisiae growing on ethanol. Jones and Kompala } \\
(1999) .\end{array}$ \\
\hline$\varphi$ & $\begin{array}{l}\text { Proportionality } \\
\text { constant for local } \\
\text { benefit in producer } \\
\text { growth }\end{array}$ & $\begin{array}{l}\text { Dimension- } \\
\text { less }\end{array}$ & $1.3 \pm 0.2$ & $\begin{array}{l}\text { Based on empirical evidence of positive assortment of } \\
\text { cooperative yeast cells, adopted from Momeni et al. } \\
\text { (2013). }\end{array}$ \\
\hline$\rho$ & $\begin{array}{l}\text { By-product } \\
\text { production/ } \\
\text { excretion }\end{array}$ & {$\left[g l^{-1}\right]^{-1}$} & $\sim 0.4-0.5$ & $\begin{array}{l}\text { Around half }(40-50 \%) \text { of each gram of glucose taken } \\
\text { up is turned into ethanol, whereas } 15 \% \text { goes to } \\
\left.\text { biomass production (see } \delta_{M}\right) \text {. The rest is lost as heat, } \\
\mathrm{CO}_{2} \text {, etc. Taherzadeh et al. (1997). }\end{array}$ \\
\hline$m$ & $\begin{array}{l}\text { Self-maintenance } \\
\text { costs \& cell death }\end{array}$ & {$[h]^{-1}$} & $0.05 \pm 0.02$ & $\begin{array}{l}\text { Adopted from Momeni et al. (2013) and Shou et al. } \\
\underline{(2007)} \text {. }\end{array}$ \\
\hline$\gamma$ & Enzyme production & {$[h]^{-1}$} & $0.03 \pm 0.02$ & $\begin{array}{l}1-5 \% \text { fitness advantage by cheaters. Giuseppin et } \\
\text { al. (1993), Christiansen and Nielsen (2002), Gore et al. } \\
\text { (2009), Momeni et al. (2013), Waite and Shou (2012). }\end{array}$ \\
\hline$\alpha$ & $\begin{array}{l}\text { Amount of delay in } \\
\text { expo-linear growth } \\
\text { on by-product }\end{array}$ & {$[h]$} & $\sim 3$ & $\begin{array}{l}\text { Yeast cells experience a lag time of } 3 \text { to } 4 \text { hours to shift } \\
\text { from glucose to ethanol. Lewis et al. (1993), Brejning } \\
\text { and Jespersen (2002), Haurie et al. (2003). }\end{array}$ \\
\hline$\beta$ & Enzyme loss & {$[h]^{-1}$} & $0.3 \pm 0.2$ & $\begin{array}{l}10-50 \% \text { of enzymes decay or become inactive every } \\
\text { hour. Bassetti et al. (2000); Folse III and Allison (2012) }\end{array}$ \\
\hline$\theta$ & $\begin{array}{l}\text { Amount of } \\
\text { additional delay in } \\
\text { expo-linear growth } \\
\text { on by-product }\end{array}$ & {$[h]$} & $3 \pm 1$ & $\begin{array}{l}\text { In accordance with the additional delay of } 3 \pm 1 \text { hours in } \\
\text { the shift from glycerol to acetate by mutant bacterium } \\
\text { with higher glycerol uptake as demonstrated by Basan } \\
\text { et al. }(2020) \text {. Same study assumes similar trade-off } \\
\text { magnitude for yeast. }\end{array}$ \\
\hline$K$ & Carrying capacity & {$\left[g^{-1}\right]$} & $\sim 30$ & $\begin{array}{l}\text { Empirically shown to range from } 20 \text { to } 55 \text {. Malairuang } \\
\text { et al. (2020). }\end{array}$ \\
\hline
\end{tabular}


Table 3. Local sensitivity analysis assuming a local benefit effect and additional delay in serial batch culture conditions. Qualitative trajectories model output for minimum and maximum 615 value of parameter range: 1) take-over followed by system collapse (blue shade), 2) no takeover and continued producer stability (i.e. stable cheater suppression, yellow shade), and 3 ) no take-over and system collapse (i.e. extinction of producer before cheater can take over, grey shade).

\begin{tabular}{|c|l|l|l|l|l|l|}
\hline Parameter & $\begin{array}{l}\text { Minimum } \\
\text { value }\end{array}$ & $\begin{array}{l}\text { Maximum } \\
\text { value }\end{array}$ & Default & Periodicity & $\begin{array}{l}\text { Output for minimum } \\
\text { value parameter }\end{array}$ & $\begin{array}{l}\text { Output for maximum } \\
\text { value parameter }\end{array}$ \\
\hline$\rho$ & 0.4 & 0.5 & 0.5 & 6 & 2 & 2 \\
\hline$m$ & 0.03 & 0.07 & 0.03 & 6 & 2 & 2 \\
\hline$\gamma$ & 0.01 & 0.05 & 0.05 & 6 & 3 & 2 \\
\hline$\alpha$ & 3 & 4 & 3 & 6 & 2 & 2 \\
\hline$\beta$ & 0.1 & 0.5 & 0.2 & 6 & 2 & 3 \\
\hline$K$ & 20 & 55 & 30 & 6 & 2 & 2 \\
\hline$\rho$ & 0.4 & 0.5 & 0.5 & 12 & 2 & 2 \\
\hline$m$ & 0.03 & 0.07 & 0.03 & 12 & 2 & 1 \\
\hline$\gamma$ & 0.01 & 0.05 & 0.05 & 12 & 3 & 2 \\
\hline$\alpha$ & 3 & 4 & 3 & 12 & 2 & 2 \\
\hline$\beta$ & 0.1 & 0.5 & 0.2 & 12 & 2 & 1 \\
\hline$K$ & 20 & 55 & 30 & 12 & 2 & 2 \\
\hline$\rho$ & 0.4 & 0.5 & 0.5 & 24 & 1 & 2 \\
\hline$m$ & 0.03 & 0.07 & 0.03 & 24 & 1 & 1 \\
\hline$\gamma$ & 0.01 & 0.05 & 0.05 & 24 & 2 & 1 \\
\hline$\alpha$ & 3 & 4 & 3 & 24 & 1 & 1 \\
\hline$\beta$ & 0.1 & 0.5 & 0.2 & 24 & 1 & 1 \\
\hline$K$ & 20 & 55 & 30 & 24 & 1 & \\
\hline & & & & & 2 \\
\hline
\end{tabular}




\section{Supplementary Figures}

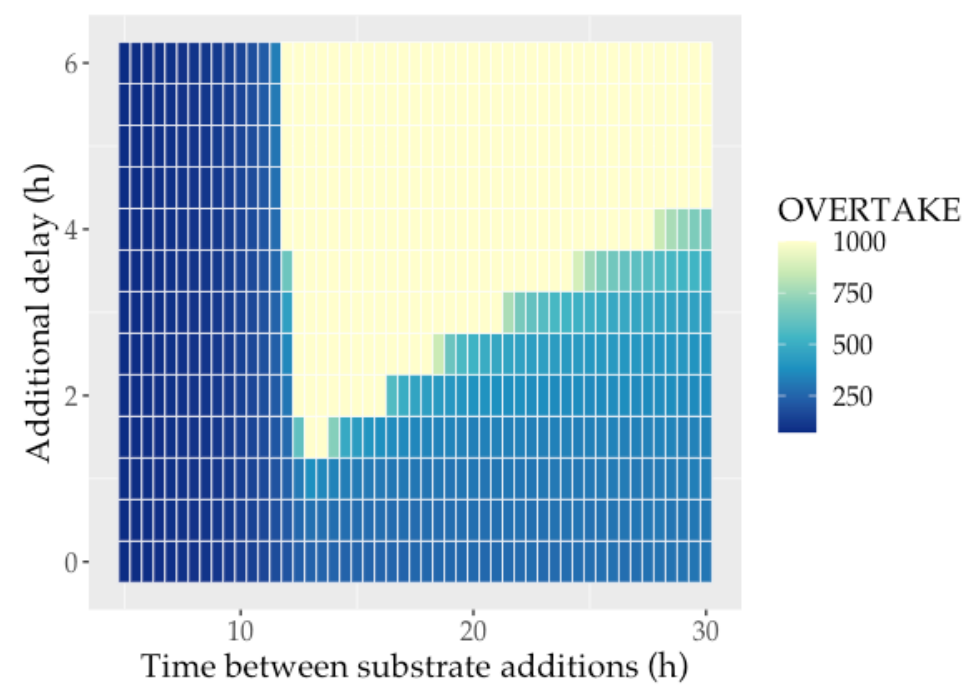

A. Conditional enzyme investment solutions, no local benefit effect (i.e. well-mixed conditions, $\varphi=1$ )

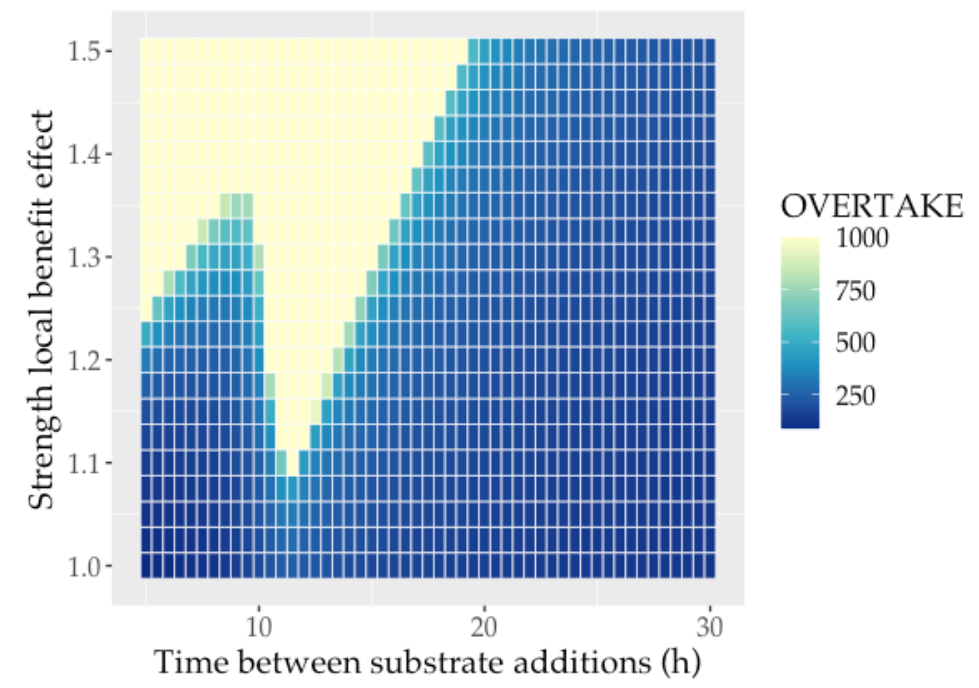

B. Solutions local benefit effect for producers, no additional delay for cheaters $(\theta=0)$ 


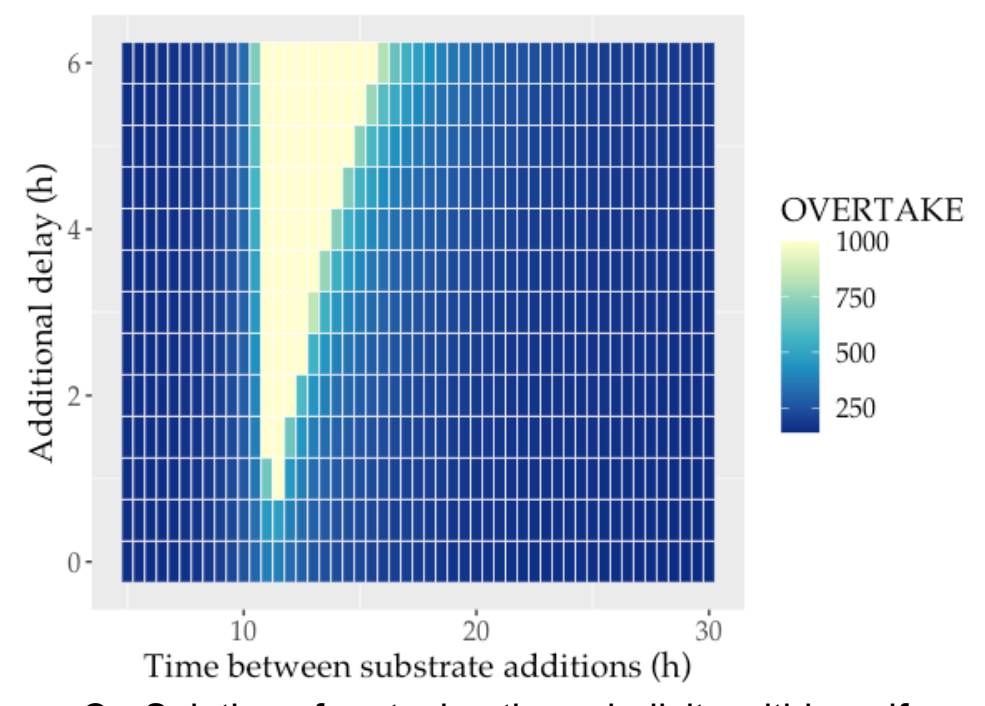

C. Solutions for stochastic periodicity within uniform range $( \pm 0.25$ interval duration $)$, with small local effect $(\varphi=1.1)$

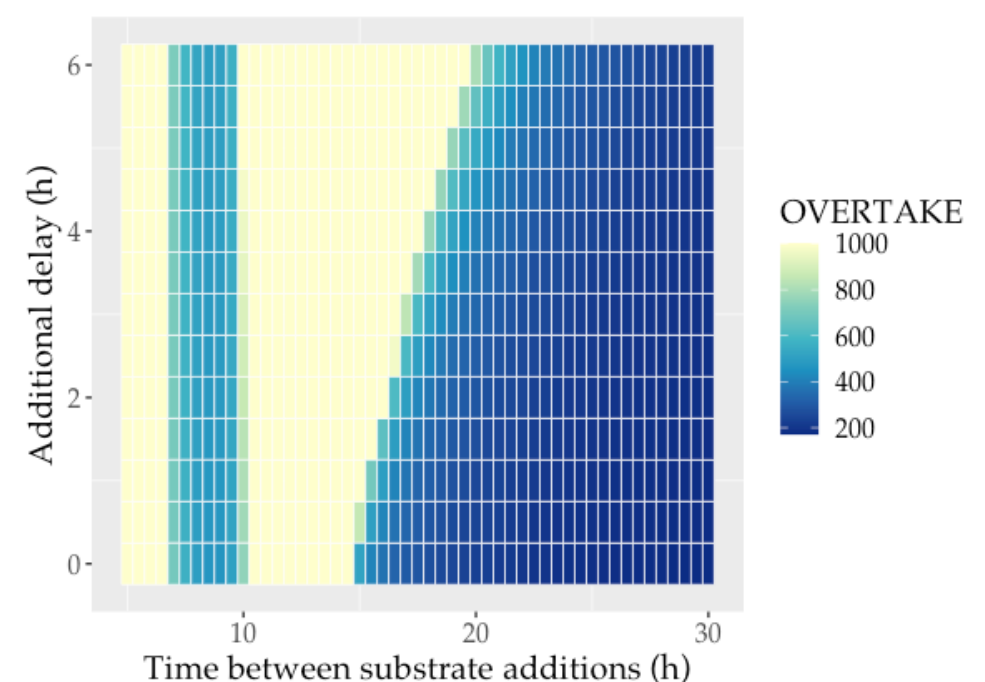

D. Solutions for stochastic periodicity within uniform range ( \pm 0.25 interval duration $)$, with intermediate local effect $(\varphi=1.3)$ 


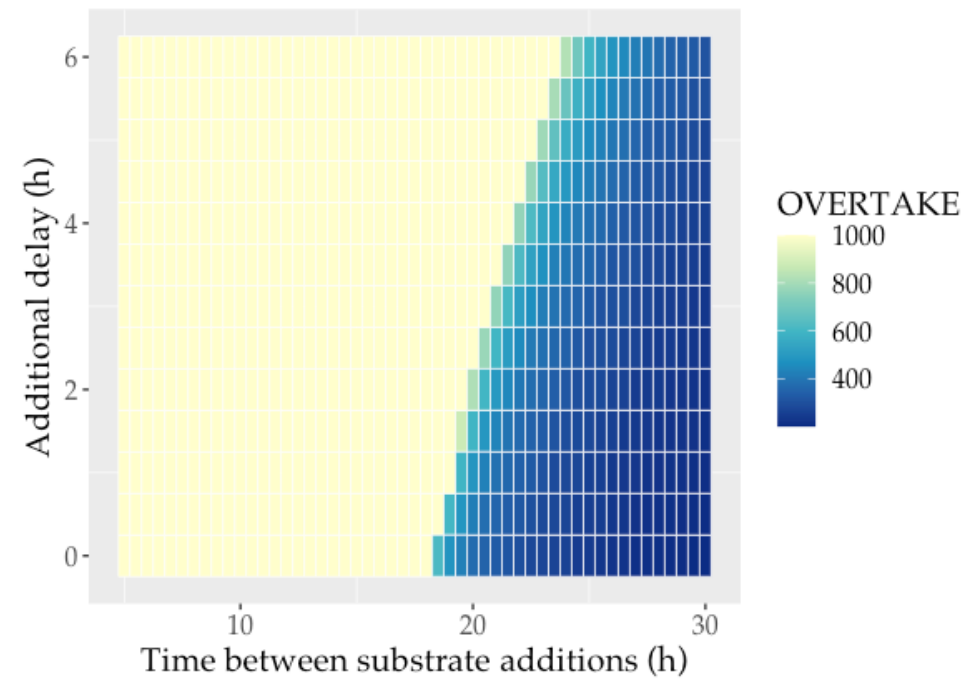

E. Solutions for stochastic periodicity within uniform range ( \pm 0.25 interval duration $)$, with strong local effect ( $\varphi=1.5$ ) 